\title{
Effect of Different Lining Materials for Reduction of Seepage Loss in Water Harvesting Structures in Ethiopia, A Review.
}

\author{
Zalalem Tamiru, Leta Hailu* \\ Jimma Agricultural Research Center, P.O. Box. 192, Jimma, Ethiopia.
}

*Corresponding Authors: Leta Hailu, Jimma Agricultural Research Center, P.O. Box. 192, Jimma, Ethiopia.

\begin{abstract}
The objective is to review the effect of different lining materials for seepage loss reduction in water harvesting structures. A large number of water harvesting technologies have been implemented with support from the government. However, these works have not been proven as successful as expected, because of technical and socioeconomic problems. The structural failures are connected with poor design; water loss due to evaporation and seepage, low technical capacity and subsequent low adoption by the user. The most critical of all the problems is the water loss due to seepage resulting from poor lining materials of the storage structures as reviewed from different literature. Hence, technologies providing good protection towards seepage loss have been given a priority. With a view of this, some research works have been conducted to identify the best lining materials that reduce water loss due to seepage. Accordingly, some study showed that mortar performed best, followed by salt with compaction and local ash. The seepage rates of the mortar, salt with compaction and local heater ash treated ponds were reduced by $89.06 \%, 39.06 \%$ and $27.34 \%$; respectively. Furthermore, bentonite showed least seepage rate of $30 \mathrm{~cm} /$ day and performed well as compared to mortar, ash lining materials and compaction in study conducted at Holeta catchment. These days, polyethylene membrane has been provided by the government to solve the problem and this membrane has been found to reduce seepage loss by $90 \%$. Unfortunately, the membrane is too costly and not easily available to all farmers. The cost estimates made have proved that the cost demand of ash and salt lined ponds is much lower than that of mortar and a geomembrane. Therefore, further study suggested to understand benefit cost ratio and suitable lining material best fit with a specific agro-ecology of the country.
\end{abstract}

Keywords: Lining material; Water resource; Water harvesting; Seepage loss

\section{INTRODUCTION}

Agriculture is only possible when there is available fresh water. Water scarcity will progressively constrain food production growth and causing adverse impacts on the goals of food security and human well-being at the alarming rate [1]. A major reason for the low and erratic rate of growth in agricultural production is uncertainty and unpredictable rainfall, combined with low soil fertility. Even in years of 'average' rainfall, a shortfall during critical periods of crop growth often leads to widespread crop failure. Therefore, water storage is absolutely crucial for stabilizing and increasing crop yields [2].

The concept water harvesting has been defined in various ways and scholars. The terminology of Water harvesting is used to indicate the collection and management of floodwater or rainwater runoff to increase water availability for domestic and agricultural use as well as ecosystem sustenance [3]. Water is harvested and directed either directly into crop fields or into various types of natural or man-made storage structures. A large variety of storage technologies are used in Eastern and Southern Africa and many of these are described and illustrated in [4;5]. In any given location, the impact of different types of storage on poverty can vary significantly, with some options being much more effective in reducing poverty than others [6]. Sufficient investment in water harvesting needs to be not only a higher priority for the semiarid regions, but also for the entire country [7]. Farm ponds and reservoirs provide a logical source of such water; they may be designed and adjusted to fit the individual land use plan [8]. According to an evaluation report made by [9], the need to exercise for supplementary water supply in Ethiopia is mainly for three reasons. These are to harvest water needed to meet own domestic needs; to provide supplementary irrigation to the long rainy season crops mainly during the drier months of September and October, and to provide full irrigation to crops during the dry months of the year. 
In arid and semi-arid regions, rainfall collected from natural or artificial surface can provide a valuable source of water. Therefore, water harvesting tanks and ponds in the village or household level are proposed as a practical and effective alternative to improve the lives of rural people in many parts of the country. According to Goshu, 2007 [10], for countries with erratic and poorly distributed water harvesting reservoirs/ponds are proving to be a promising answer to the problem of storing water to supplement agricultural production and other uses. However, these small ponds were being faced with challenges of losing relatively large amount of water due to seepage, improper lining especially poor selection and application of liners. Most of the water harvesting structures was not sufficiently effective in storing the collected water. Statistics of different study reveal that seepage loss in unlined pond accounts for about $45 \%$ of the total storage and evaporation loss accounts for $25 \%$. The main problem, in this regard, is that the selection and application of lining materials have not been comprehensively investigated and demonstrated in terms of their effectiveness and efficiency. Moreover, most structures were constructed in the same procedure without considering differences in the soil type. To prevent the seepage and other losses from the water body, ponds should be lined with suitable materials. Therefore, the aim of this review is to identify the effect of different lining materials for reducing seepage loss in water harvesting structures.

\section{OVERVIEW OF WATER HARVESTING TECHNOLOGY IN ETHIOPIA}

\subsection{Water Resources of Ethiopia}

Ethiopia has abundant water resources that could be developed for, among other things, irrigation, in order to de-link the performance of the economy from rainfall variability. Given the importance of agriculture to the Ethiopian national economy, the Government of Ethiopia has embarked on an agriculture-led development programmed with irrigation development a central component. It is estimated that only $5 \%$ of 3.5 million ha of land that could be irrigated is currently developed $[11 ; 12]$. Irrigation is one of the means by which agricultural production can be increased to meet the growing demands in Ethiopia. A various study conducted indicated that one of the best alternatives to consider for sustainable food security development is expanding irrigation development on various scales, through river diversion, constructing micro-dams and water harvesting structures [11].

Ethiopia has endowed with huge surface water and groundwater resource potential, according to the current knowledge, the country has about 124.4 billion cubic meters (BCM) river water, 70 BCM lake water, and $30 \mathrm{BCM}$ groundwater resources [13]. Although Ethiopia's water resource is large, very little of it has been developed for agriculture and other purposes. Excluding the purely pastoralist areas, more than 90 woreda with a total of more than 2 million households in the country are drought prone and regularly hit by severe water shortages. This seriously threatens the lives of more than 12 million people. The major factors contributing to the current food insecurity include widening gap between the level of food production and the rapid population growth, degradation of natural resource base and dominance of cereal based farming system which is exclusively dependent on rain fed cultivation together with erratic and unreliable nature of the rain fall. The main source of water for irrigation, livestock consumption and domestic use in Ethiopia is mainly from rivers/streams, ground water, lakes and artificial ponds and surface water (seasonal). The distribution of these sources is uneven, in some areas abundant and in others scarce. This variability is mainly due to the diversified landscape and agroclimatic condition the country owns [14]. "Green water" i.e., rainfall as reported by [15], is the major source of agricultural water in Ethiopia.

\subsection{Water Harvesting}

Water harvesting has been defined as the collection of runoff for its productive use (3). However, more comprehensively, water harvesting has been defined by Reijntjes, 1983 as cited in [16] to mean all the different techniques to collect runoff or flood water for storage in the soil profile or in tanks so that it can be used for the production of crops, trees or fodder. Presently water harvesting is gaining importance in many rural areas especially in developing countries like Ethiopia to combat drought hazards.

Benefits of water harvesting: The benefits of water harvesting also can be viewed from different direction. As Yang [17], supplemental irrigation for dry-spell to mitigate rain fed agriculture is quite useful. According to Fax [18] investigation the benefit of supplemental irrigation practices water harvesting structure such as earthen ponds in small plot of land at a household level. Water harvesting in this case can be viewed as a tool for small holder farmers to stabilize crop water supply and there by increased fields cultivated and create incentives for increased investments. 
When crop yields in the tropical dry lands farming area is constrained by water deficits paradoxically significant portions of rain water flows out and wasted as surface runoff could be harvested properly and stored for later use, therefore water harvesting practice is quite essential and it is beneficial at the house hold level and would be able to bring food security. Water harvesting is far more widely used than often perceived in semi-arid regions of countries like Tunisia, Morocco, Israel, Yemen and India [19].

Challenges of water harvesting in Ethiopia: According to [20], the difficulties obstructing the promotion of the water harvesting schemes in most regions of Ethiopia are: being implemented under intense pressure to achieve figurative results, which undermines the quality of the structures, Site selection and construction works are being done by inexperienced professionals and masons resulting in low water entrance to the tanks, damage by runoff, siltation, loss of productive land, severe seepage from storages, with the consequences that many project fail. In many places, the schemes implemented are not the most appropriate ones. Furthermore [20] reported, from his field observation, that the structures themselves have problems with layout and design and plastic lined ponds heat up, increasing already high evaporation rates or if covered with stones they are in danger of getting pierced and leak. Many concrete tanks were found to be leaking due to poor mix of cement and sand and poor curing procedures of the surfaces of the storage ponds.

\subsection{Types of Water Harvesting Techniques}

The various types of water harvesting techniques are also classified as rainwater harvesting, floodwater harvesting and groundwater harvesting [21]. Another grouping of water harvesting systems based on the sources of water from feeder is micro-catchment and macro catchment. Further classification with respect to the storage media includes structural storage and soil storage.

Rainwater harvesting: It is defined as a method for inducing, collecting, storing and conserving local surface runoff for agriculture in arid and semi-arid regions [21]. Rainwater harvesting techniques can be classified as: (i) roof harvesting; (ii) runoff harvesting; and (iii) flood harvesting. They pointed out that rainwater harvesting covers three types of water harvesting. These are compacted or treated surface harvesting, micro catchment and macro-catchment. Water collected from roof tops, courtyards and similar treated or compacted surfaces can be used for domestic purpose or garden crops and microcatchment water harvesting is a method of collecting surface runoff from a small catchment area and storing it in the root zone of an adjacent infiltration basin.

Macro-catchments water harvesting also called harvesting from external catchments is the case where runoff from hill-slope catchments is conveyed to the cropping area located at the hill foot on flat terrain. Efficient collection and storage of rainwater is critical in food insecure areas with increasing pressure on land.

Flood water harvesting: [21] defined floodwater harvesting as the collection and storage of creek flow for irrigation use. They stated that floodwater harvesting also known as large catchment water harvesting or spate irrigation may be classified into streambed harvesting and floodwater diversion. In case of floodwater harvesting with in streambed, the water flow is dammed and as a result inundates the valley bottom of the flood plain. The water is forced to infiltrate and the wetted area can be used for agriculture or pasture improvement.

Ground water harvesting: It is a new term and employed to cover traditional as well as unconventional ways of groundwater extraction [21]. They further stated that groundwater dams (subsurface dams and sand storage dams), underground dams and special types of wells are few examples of the groundwater harvesting techniques. These structures obstruct the flow of ephemeral streams in a riverbed; the water is stored in the sediment, ground surface and can be used for aquifer recharge.

\subsection{Type of Water Harvesting Structures}

In general, there are multitudes of technologies potentially feasible for use in water harvesting system for arid and semi-arid areas. Currently, inspired by the water harvesting systems of Tunisia, India, and Israel, realizing the importance of such systems for semiarid regions, several development organizations have initiated different water harvesting projects in African countries [22]. Water can be extracted from the hydrological cycle at various points and stored by different water harvesting structures to fulfill agricultural or domestic consumption. If water is intercepted by roof drainage before it touches the ground or by surface run-off from the ground before it percolated down ward, then the storage device used to store the water in these cases could be a cistern, detention basin or storage ponds [23] 
Short-Term Runoff Harvesting Techniques: As it rains; part of the water will wet the ground and be stored in depressions, or lost through evaporation or infiltration. Some water conservation methods such as mulching, deep tillage, contour farming and ridging are often referred to as in situ rainwater harvesting techniques [24]. The purpose of these methods is to ensure that rainwater is held long enough on the cropped area to allow more water infiltration into the soil.

Long-Term Runoff Harvesting Techniques: The most common long-term runoff harvesting structures are dugout ponds and embankment type reservoirs. Dugout ponds are constructed by excavating the soil from the ground surface. Ground water, or surface runoff or both may feed into these ponds. Underground storage Cisterns/tanks are more commonly used in India, China and several other countries. Cisterns have been also used recently in Ethiopia during the year 2002/3 at the household level to supplement the rain fed farming by adopting supplementary irrigation practices [22].

Dugout ponds involve more construction costs and therefore are generally recommended when embankment type ponds are not economically feasible for construction. It becomes an alternative in arid and semi-arid regions, where precipitation is low or infrequent during the dry season and there is a need to store the maximum amount of rainwater during the wet season for use at a later time, especially for agricultural and domestic water supply [25]. The embankment dam is constructed by damming across a valley or depression of a watershed. The storage capacity of the reservoir is determined on the basis of water requirement for various demands and available surface runoffs from the watershed.

\subsection{Definition and Scope of Farm Pond}

Farm pond was defined as a useful hydraulic structure constructed for storing water essentially from surface runoff, to make available for crops, livestock and other miscellaneous purposes [8]. It is proven to be effective means of storing water during rainy season to solve several purposes of farm needs: to save crops from failure by using supplementary irrigation during critical growth periods. Based on the source of water and land use feature, ponds can be categorized into embankment pond and excavated ponds as well as off the creek or stream fed ponds. Embankment ponds generally impounded water behind in earthen dam whereas excavated ponds are dug out type pond constructed by excavating the soil from the ground relatively in level areas

\subsection{Types of Ponds}

Embankment Pond: An embankment pond is a body of water created by constructing a dam across a stream or water course. These ponds usually are built in areas where land slopes range from gentle to moderately steep and where stream valleys are sufficiently depressed to permit the storage of water to a considerable depth [26].

Excavated Pond: An excavated pond is a body of water created by excavating a pit on dugout. These, usually, constructed in relatively leveled areas. They are usually used in areas where only a small supply of water is required [26]. Farm pond is among the different water harvesting structures employed at the farmer's level in Ethiopia, this structure is being implemented at the house hold level to store 120-150 $\mathrm{m}^{3}$ of water for supplemental irrigation [27].

\subsection{Water Loss in Storage Pond}

Evaporation Loss: Evaporation losses are high in arid regions while transpiration is the major water loss in humid regions. Evaporation losses mainly depend upon the reservoir surface area [ 28,29]. The other factors influencing evaporation are temperature, wind velocity, relative humidity 8,29].

Seepage Loss: Seepage loss takes place when there is difference in water levels on the two sides of a structure such as dams or a sheet pile or ponds. It may occur through the bed and wall material [30]. Seepage from storage ponds affects the efficient utilization of water resources.

Common Causes of Seepage: As stated by [31], the most common causes of water loss due to seepage from water storage structures are poor quality of the construction work, poor soil compaction and lining, failure to remove the topsoil and vegetation at the storage site, use of an unsuitable soil type in the wall, failure to backfill exposed rock, gravel or sand in the storage basin, improper site selection, geological formation of the soil and poor maintenance of the storage.

Factors Influencing Seepage Losses: Seepage losses are influenced by soil factors. Soil functions essentially as a previous medium that provides a large number of passageways for water to move into the soil. In general, the size of the passage ways and the seepage into the soil, according to [32], are dependent on the size of the particles that make up the soil, the degree of aggregation between the 
Effect of Different Lining Materials for Reduction of Seepage Loss in Water Harvesting Structures in Ethiopia, A Review.

individual particles and the arrangement of the particles and aggregates. The larger the pore size and the greater the continuity of the pores that can be maintained, the greater is the resulting seepage loss.

Seepage Loss Control: Lining the surface of the structures can reduce seepage losses. Losses from seepage can some extent to be reduced by proper site selection, avoiding sands and gravels [28] and by completely or partly sealing the soil surface using lining materials (chemicals and/or cement or others) [3]. Three methods of seepage loss control are reported to be effective in silt loam soil in Islamabad [33]. These methods are classified as chemical, physical and biological methods of seepage loss control.

\subsection{Lessons Obtained in Reducing Seepage Loss}

According to [10], lining of ponds with mortar performed best in reduction of seepage loss by $(89.06 \%)$, followed by salt with compaction (39.06\%) and local ash (27.34\%). The average seepage rate of ponds lined with mortar was the least seepage rate, which accounted to a reduction of seepage as compared with the compaction and local ash.

Table1. Seepage rates of different of lining materials

\begin{tabular}{|l|l|}
\hline Treatment & Seepage rate $(\mathrm{mm} /$ day $)$ \\
\hline Mortar & 1.4 \\
\hline Ash & 9.3 \\
\hline Salt + compaction & 7.8 \\
\hline Compaction & 15.8 \\
\hline Salt alone & 12.8 \\
\hline
\end{tabular}

Source: [10].

Lining materials of cement-sand mixture (1:3) with $5 \mathrm{~cm}$ and $2.5 \mathrm{~cm}$ thickness exhibited good performance in controlling seepage loss. Looking into the results of seepage rate of each lining ratio the rich mixture (1:3 cement-sand ratios) was better in controlling seepage rate irrespective of their thickness [34].

Table2. Seepage rate in mixtures of cement

\begin{tabular}{|l|l|}
\hline Treatment & Seepage rate $(\mathrm{mm} / \mathrm{day})$ \\
\hline $1: 3$ Cement to sand $(5 \mathrm{~cm}$ thick $)$ & 1.18 \\
\hline $1: 5$ Cement to sand $(5 \mathrm{~cm}$ thick & 2.31 \\
\hline $1: 3$ Cement to sand $(2.5 \mathrm{~cm}$ thick & 1.7 \\
\hline Unlined & 9.46 \\
\hline
\end{tabular}

Source: [34].

Compaction was performed to densely pack the materials meanwhile to reduce permeability and enhance water holding capacity while they are installed in earthen ponds [22]. Therefore, the result of this achievement confirm that after compaction the total voids which can be available for water flow in the existing soil has reduced by $51.1 \%$, so that the permeability (seepage loss) from ponds treated with such treatments can be reduced significantly. Compaction showed a reduction of $23.44 \%$ as compared with salt treated ponds. The observation made on four ponds using compaction alone as method of lining by its own has showed a reduction in seepage loss right from the start of the study period [10]. Geomebrane lined pond show better storage efficiency than other treatments in luvisols soil. These days, polyethylene membrane has been provided by the government to solve the problem and this membrane has been found to reduce seepage loss by $90 \%$ [35]. Unfortunately, the membrane is too costly and not easily available to all farmers [22]. On other study conducted at Holeta catchment, bentonite showed least seepage rate of $30 \mathrm{~cm} /$ day and performed well as compared to mortar, ash lining materials and compaction [36]. Plastic can be used very effectively in lining the ponds [26]. However, lining the ponds with plastics as a barrier material, sufficient care is required in selecting the proper material and lying of plastics material and saving it from the damage. In view of the important role played by the plastic film in lining of ponds, it is essential that systematic procedures are to be laid down for plastic lined ponds. Therefore, various study conducted on lining material at different location were exhibited different potential of compared lining materials. Thus, using the best fit lining materials in terms of cost and availability to all users is essential to reduce seepage loss and sustain the benefit obtained from the water harvesting technology. 
Effect of Different Lining Materials for Reduction of Seepage Loss in Water Harvesting Structures in Ethiopia, A Review.

\section{CONCLUSION}

Water harvesting technologies are being promoted at the household level in most Ethiopian regions. Among the different types of surface run-off water harvesting structures, earthen pond is the major one practiced by many farmers. Huge number of earthen ponds have been implemented to date in different site. However, the problems of seepage yet not adequately addressed and loss of water from the ponds due to seepage and evaporation has been reducing the performance of the ponds in many areas.

The structural failures are connected with poor design, water loss due to evaporation and seepage, low technical capacity and subsequently low adoption by user. The most critical of all the problems is the water loses due to seepage resulting from poor lining materials of the harvesting storage structures. Hence technologies providing good protection towards seepage loss have been given a priority. With a view of this, some research works have been conducted to identify the best lining materials that reduce water loss due to seepage and different lining materials were investigated and evaluated in Ethiopia to improve storage efficiency of small household water harvesting ponds. On different type of soil for instance like; Luvisols and vertisols, different types of pond lining techniques were investigated and evaluated.

Accordingly, mortar performed best, followed by salt with compaction and local ash in some study. Another study also concluded that the rich mixture (1:3 Cement to sand ratio) was better in controlling the seepage rate than the lean mixture (1:5 cement to sand ratio). These days, polyethylene membrane has been provided by the government to solve the problem and this membrane has been found to reduce seepage loss by $90 \%$. Unfortunately, the membrane is too costly and not easily available to all farmers. The cement-sand mixtures exhibited better performance followed by salt with compaction and local heater ash. The cost estimates made have proved that the cost demand of ash and salt lined ponds is much lower than that of mortar and geomembrane. Compaction by itself has good capacity in increasing impermeability, especially in clay soils. But, in many areas seepage from compacted storages at household level is not practically tolerable as it reduces the water available for different use. Therefore, it is better when supplemented with other methods to employ it as a method to reduce seepage.

\section{REFERENCES}

[1] Rosegrant, M. W., Ringler, C., \& Zhu, T. (2009). Water for agriculture: maintaining food security under growing scarcity. Annual review of Environment and resources, 34.

[2] FAO (Food and Agriculture Organization of the United Nations). 2003. A Perspective on Water Control in Southern Africa: Support to Regional Investment Initiatives. Land and Water Discussion Paper 1. AO, Rome, Italy.

[3] Mekdaschi Studer, R. and Liniger, H. 2013. Water Harvesting: Guidelines to Good Practice. Centre for Development and Environment (CDE), Bern; Rainwater Harvesting Implementation Network (RAIN), Amsterdam; MetaMeta, Wageningen; The International Fund for Agricultural Development (IFAD), Rome.

[4] Ngigi, S. N. (2003). What is the limit of up-scaling rainwater harvesting in a river basin?. Physics and Chemistry of the Earth, Parts A/B/C, 28(20-27), 943-956.

[5] Mati, B. M. (2006). Overview of water and soil nutrient management under smallholder rain-fed agriculture in East Africa (Vol. 105). IWMI.

[6] Hagos, F.; Jayasinghe, G.; Awulachew, S.B.; Loulseged, M.; Yilma, A.D. 2012. Agricultural Water Management and Poverty in Ethiopia. Agricultural conomics 43(Supplement S1): 99-111.

[7] Kidane W/GiGiorgis, 2001. Water Harvesting: The Key to Successful Crop Production and Resource Management in Water Stress Environments: Eastern Africa Experience, in:Mitiku Hailu and Sorssanatea merga (Eds.), Proceedings of the International Workshop on: The Experience of Water Harvesting in the Dry Lands of Ethiopia: Principles and Practices, Mekelle, Ethiopia.

[8] Taffa Tulu, 2002. Soil and Water Conservation for Sustainable Agriculture. Mega Publishing Enterprise, Addis Ababa, Ethiopia.

[9] EU (European Union), 2004. Evaluation of the Water Harvesting Schemes Component of the EC.

[10] Goshu Worku, 2007. Evaluation of Lining Materials to Reduce Seepage Loss for Water Harvesting Ponds. Sc Thesis Submitted to Haramaya University, Ethiopia.

[11] Selesh A. B., Merrey, D., Kamara, A., Van Koppen, B., Penning de Vries, F., \& Boelee, E. (2005). Experiences and opportunities for promoting small-scale/micro irrigation and rainwater harvesting for food security in Ethiopia (Vol. 98). IWMI.

[12] Fitsum Hagos, Makombe, G., Namara, R.E., and Seleshi Bekele. 2010 Importance of irrigated agriculture to the Ethiopian economy: Capturing the direct net benefits of irrigation. Ethiopian J.Dev. Res.32 (1) $5-55$. 
Effect of Different Lining Materials for Reduction of Seepage Loss in Water Harvesting Structures in Ethiopia, A Review.

[13] Berhanu, B., Seleshi, Y., \&Melesse, A. M. (2014). Surface water and groundwater resources of Ethiopia: potentials and challenges of water resources development. In Nile River Basin (pp. 97-117). Springer, Cham.

[14] Hugo R. 2003. Ponds Filled with challenges. Water Harvesting Experiances in Amhara and Tigray, UNOCAEthiopia. Assessment Mission, 2003.

[15] Awulachew, S.B., Merry, D.J., Kamara, A.B., Van Koppen, B., Penning De Vries, F., 2005. Experience and Opportunities for Promoting SmallScale/Micro-Irrigation and Rainwater Harvesting for Food Security in Ethiopia. (Working Paper 98. Colombo, IWMI, Sirilanka. V. 86p.

[16] Critchley, Will and Klaus Siegert. "A Manual for the Design and Construction of Water Harvesting Schemes for Plant Production." 17/1991. FAO Corporate Document Repository. http://www.fao.org/docrep/U3160E/u3160e00.htm\#Contents.

[17] Young, E.G. 1994, seepage to ditch from a ponded surface. J. Hydrology. Amsterdam. 161(1-4):145-154.

[18] Fax, P.R., 2003, Supplemental Irrigation for Dry-Spell Mitigation of Rain fed Agriculture in the Sahel,J-Nat. Res. Mang.Dept Stockholm University. 61(1): 29-50.

[19] LEIS, 2005. Termite Mound Soil as Fertilizing the Soil.J. Center for Low External in Puts Sustainable Agriculture.21 (2):29.

[20] Rämi, H. (2003), "Ponds Filled with Challenges: Water Harvesting Experiences from Amhara and Tigray", United Nations Office for the Coordination of Humanitarian Affairs Ethiopia, UNOCHA, Ethiopia.

[21] Prinz, D. and Singh, A.K. 2000. Technology Potential for Improvements of Water Harvesting. Thematic Review IV.2: Assessment of Irrigation Options. Contributing Paper: World Commission on Dams. Cape Town, South Africa.

[22] Dereje Mamo, 2005. Investigating Alternative Methods for Reducing Seepage Loss from Earthen Ponds. MSc Thesis Submitted to Haramaya University, Ethiopia.

[23]FAO, 1994. Water harvesting for improved Agricultural Production. Proceedings of the Food and Agricultural Organization of the UN (FAO), Expert Consultation, November 1993, Cairo, Egypt.

[24] Habitu, N, and H. Mahoo. 1999. Rainwater Harvesting Technologies for Agricultural Production: A Case for Dodomia, Tanzania. In: P.G. Kambutho and T.E. Simalenga (Eds). Conservation Tillage with Animal Traction. A Resource Book of Animal Traction Network for Eastern and Southern Africa (ATNESA). Harare, Zimbabwe.

[25] OAS (Organization of American States). 1997. Source Book of Alternative Technologies for Freshwater Augmentation in Latin America and the Caribbean. Unit of Sustainable Development and Environment General Secretariat, Organization of American States Washington, D.C.

[26] Ashwani Kumar and Rajbir Singh 2010. Plastic Lining for Water Storage Structures.

[27] OIDA, 2001. Water Harvesting Packages at the House Hold Level. Extension Bulletin. Irrigation Development Authority, Addis Ababa.

[28] Hudson, N.W. 1987. Soil and Water Conservation in Semi-Arid Areas. FAO Land Water Management Division, FAO, Rome. Islamabad, Pakistan, and Agricultural Water Management 30: 67-76.

[29] Garg, S.K. 1999. Irrigation Engineering \& Hydraulic Structures. 8th Ed. Khanna Publishers,Delhi, India, P1442.

[30] Kumar, C.P. 2006. Assessment of Groundwater Potential. National Institute of Hydrology.

[31] Yiasoumi, B. (2004). Leaking farm dams. NSW Department of Primary Industries.

[32] Neibling, H. and D. Falk (1997). Design and Construction of Earthen Embankments for Animal Liquid-Waste Containment. University of Idaho. College of Agriculture Cooperative Extension System. Agric. Experiment Station \#CIS1053.

[33] Ahmad, S., Aslam, M. and Shafiq, M. 1996. Reducing Water Seepage from

[34] Asegdew Gashaw, 2005. Evaluating Slope Stability and Different Cement-Sand Mix Ratio

[35] Getaneh, M. and Tsigae, A. 2013, "Comparative analysis of lining materials for reduction of seepage in water harvesting structures, Adet, Ethiopia”, International Journal of Development and Sustainability, Vol. 2 No. 2, pp. 1623-1635.

[36] Mahtsente T. and Kidist H. 2019. Low cost and Efficient Lining Material for Seepage Lose Control on Water Harvesting Structures at Holeta Catchment, Ethiopia. International journal of Novel Research in Life Sciences, 6(1), pp:46-53.

Citation: Leta Hailu \& Zalalem Tamiru “ Effect of Different Lining Materials for Reduction of Seepage Loss in Water Harvesting Structures in Ethiopia, A Review. ” International Journal of Research Studies in Agricultural Sciences (IJRSAS), 2021; 7(1), pp. 17-23, https://doi.org/10.20431/2454-6224.0701002

Copyright: (0) 2021 Authors. This is an open-access article distributed under the terms of the Creative Commons Attribution License, which permits unrestricted use, distribution, and reproduction in any medium, provided the original author and source are credited. 